\title{
Strategi Konselor dalam Membantu Penyesuaian Diri Anak Berkebutuhan Khusus di Era Milenial
}

\author{
Muhammad Naili Rizki Setiawan \\ Institut Agama Islam Negeri (IAIN) Kudus \\ naili.rizkia1@gmail.com \\ Fitria Khoirunnisaa' \\ Institut Agama Islam Negeri (IAIN) Kudus \\ fitriannis08@gmail.com \\ Arina Fithriyana \\ Institut Agama Islam Negeri (IAIN) Kudus \\ arinaf@iainkudus.ac.id
}

\begin{abstract}
Abstrak
Pesatnya arus globalisasi membuat setiap manusia harus mampu menyesuaikan dirinya dengan perkembangan zaman. Tidak semua individu mengalami perkembangan normal. Beberapa diantaranya mengalami hambatan, gangguan, atau memiliki faktor resiko sehingga dalam perkembangannya yang optimal diperlukan penanganan husus. Kelompok ini disebut sebagai individu berkebutuhan khusus atau akrab diistilahkan disabilitas. Strategi dalam proses pendidikan menjadi sebuah keniscayaan yang harus disiapkan oleh seorang konselor. Tujuan penelitian ini adalah untuk mengetahui bagaimana strategi konselor dalam proses bimbingan konseling yang pas terhadap ABK dalam proses penyesuaian diri di era milenial. Dalam kajian ini, penulis menggunakan pendekatan penelitian kualitatif dengan objek kajian pondok pesantren disabilitas Achsaniyyah Pedawang Kab. Kudus. Dari kajian ini, didapatkan hasil bahwa proses kelas pembelajaran terbagi menjadi beberapa, diantaranya kelas one by one, pra-mandiri, dan kelas mandiri. Penyelenggaraan sekolah dan strategi ABK tersebut diharapkan mampu menciptakan dan mewujudkan ABK yang mandiri, mampu menyelesaikan masalah yang dihadapinya, dan mampu menyesuaikan diri dengan lingkungan yang berbeda.
\end{abstract}


Kata kunci: Strategi Konselor, Penyesuaian Diri, Anak Berkebutuhan Khusus (ABK), Era milenial.

\begin{abstract}
COUNSELOR STRATEGIES IN ASSISTING SELF-ADJUSTMENT OF CHILDREN WITH SPECIAL NEEDS IN MILLENNIAL ERA. The rapid flow of globalization makes every human being must be able to adapt himself to the times. Not all individuals experience normal development. Some of them experience obstacles, disorders, or have risk factors so that in optimal development special handling is needed. This group is referred to as individuals with special or familiar needs termed disability. The strategy in the education process is a necessity that must be prepared by a counselor. The purpose of this study was to find out how the counselor's strategy in the process of counseling is appropriate for $A B K$ in the process of self-adjustment in the millennial era. In this study, the authors used a qualitative research approach with the object of study in the Achsaniyyah Pedawang disability Islamic boarding school. From this study, it was found that the learning class process was divided into several, including one by one, pre-independent, and independent classes. The organization of the school and the $A B K$ strategy are expected to be able to create and realize independent crew members, able to solve problems they face, and be able to adapt to different environments.
\end{abstract}

Keywords: Strategy of Counselors, Self-Adjustment, Children with Special Needs (ABK), Millennial Era.

\title{
A. Pendahuluan
}

Perkembangan zaman yang pesat saat ini, menimbulkan perubahan dan kemajuan dalam berbagai aspek kehidupan masyarakat. Sehingga setiap individu menghadapi permasalahan yang semakin kompleks diantaranya dalam permasalahan bidang pendidikan, sosial, keluarga, pribadi hingga sekolah. Dalam hal ini individu harus mampu melakukan penyesuaian-penyesuaian diri terhadap perkembangan zaman tersebut. Tempat untuk menyiapkan perkembangan zaman tersebut salah satunya adalah di lingkungan sekolah. Sekolah harus mampu 
membantu murid-muridnya dalam menyelesaikan masalah-masalah yang dihadapi.

Pada dasarnya, kehidupan manusia tidak pernah statis sejak lahir sampai meninggal. Setiap individu selalu mengalami perubahan. Perubahan yang dialami merupakan integrasi dari berbagai perubahan struktur dan fungsi sehingga memengaruhi perkembangan fisik, kognisi, emosi, sosial, dan kepribadian (Rahman, 2016: 139). Individu yang tidak semuanya mampu melewati setiap tahapan perkembangan. Banyak anak yang memiliki keterbatasan fungsional seperti tunanetra, tunarungu, dan autis. Selain itu, ada juga anak yang memiliki kekhususan lain seperti mengalami gangguan pemusatan perhatian (ADHD), kesuliltan belajar (disleksia, disgrafia, diskakulia), dan lembat belajar (slow learner). Individu yang memiliki disabilitas sering disebut sebagai anak berkebutuhan khusus (ABK).

Anak berkebutuhan khusus juga perlu mendapatkan layanan bimbingan dan konseling. Menurut Prayitno (dalam Kamaluddin, 2011:448), bimbingan dan konseling adalah pelayanan bantuan untuk peserta didik, baik secara perorangan maupun kelompok agar mandiri dan bisa berkembang secara optimal, dalam bimbingan pribadi, sosial, belajar maupun karier melalui berbagai jenis layanan dan kegiatan pendukung berdasarkan norma-norma yang berlaku. Dalam ruang lingkup bimbingan dan konseling, pemberian layanan tidak hanya ditujukan atau diberikan pada anak normal saja. Karena dalam pandangan sebagaian besar masyarakat terhadap anak berkebutuhan khusus (ABK), masih banyak yang terabaikan sampai saat ini bahkan merasa terkucilkan. Kondisi tersebut tentunya membawa dampak langsung maupun tidak langsung terhadap tumbuh kembang ABK, bahkan terhadap keluarganya (kedua orangtuanya).

Anak berkebutuhan khusus atau yang pada masa lampau disebut anak cacat memiliki karakteristik khusus dan kemampuan yang berbeda dengan anak-anak pada umumnya. Tipe anak berkebutuhan khusus bermacam-macam dengan penyebutan yang sesuai dengan bagian dari anak yang mengalami hambatan baik 
telah ada sejak lahir maupun karena kegagalan atau kecelakaan pada masa tumbuh-kembangnya.

Menurut Kauffman \& Hallahan (dalam Chamidah, 2010:1), tipe-tipe kebutuhan khusus yang selama ini menyita perhatian orang tua dan guru adalah (1) tunagrahita (mental retardation) atau anak dengan hambatan perkembangan (child with development impairment), (2) kesulitan belajar (learning disabilities) atau anak yang berprestasi rendah, (3) hiperaktif (attention deficit disorder with hyperactive), (4) tunalaras (emotional and behavioural disorder), (5) tunarungu wicara (communication disorder and deafness), (6) tunanetra atau anak dengan hambatan penglihatan (partially seingand legally blind), (7) autistik, (8) tunadaksa (physical handicapped), dan (9) anak berbakat (giftedness and special talents). Di dalam Peraturan Menteri Pendidikan Nasional Republik Indonesia tentang Pendidikan Inklusif yang memiliki kelainan dan memiliki potensi kecerdasan dan/atau bakat istimewa menetapkan bahwa peserta didik berkelainan terdiri atas peserta didik yang: a. tunanetra; b. tuna rungu; c. tunawicara; d. tunagrahita; e. tunadaksa; f. tunalaras; g. kesulitan belajar; h. lamban belajar; i. autis; j. memiliki gangguan motorik; k. menjadi korban penyalahgunaan narkotika, obat terlarang, dan zat adiktif lain; dan l. memiliki kelainan lainnya; m. tunaganda (Permendiknas, 2009).

Anak berkebutuhan khusus seringkali mendapatkan hambatan, kesulitan dan masalah sebagai dampak keluarbiasaannya. Dampak yang dirasakan berupa aktivitas sehari-hari dan pembatasan beraktivitas di lingkungannya. Selain itu, keterbatasan ekonomi dan kurangnya pengetahuan keluarga terhadap gejala, penyebab, dan dampak anak berkebutuhan khusus dianggap menjadi faktor yang kurang mendukung tumbuh kembang anak. Untuk mengatasi hal tersebut, perlu adanya pemberian bantuan terhadap ABK agar mereka mampu berkembang. Bantuan yang diberikan tentunya fokus pada pengembangan kepribadian dan keterampilan hidup bagi ABK. 
Anak berkebutuhan khusus berhak untuk memeroleh pendidikan yang layak seperti orang yang normal. Hak atas pendidikan sebagai bagian dari hak asasi manusia di Indonesia tidak sekadar hak moral melainkan juga hak konstitusional. Hal ini sesuai dengan ketentuan UUD 1945 (amandemen), khususnya Pasal 28 C Ayat 1 yang menyatakan, "Setiap orang berhak mengembangkan diri melalui pemenuhan kebutuhan dasarnya, berhak memeroleh pendidikan dan memeroleh manfaat dari ilmu pengetahuan dan teknologi, seni, dan budaya, demi meningkatkan kualitas hidupnya dan demi kesejahteraan umat manusia. Hak tersebut bukan hanya sekedar untuk anak normal tetapi anak berkebutuhan khusus juga mendapat hak penuh dalam memeroleh pendidikan (Undang-Undang Dasar 1945 \& Konstitusi Indonesia, 2006).

Pondok Pesantren Disabilitas Achsaniyyah Pedawang Kudus merupakan salah satu tempat pendidikan khusus anak berkebutuhan khusus yang terletak di Kabupaten Kudus. Rata-rata siswa-siswi atau santri yang ada disini adalah penyandang autis dan keterbelakangan mental (Tuna Grahita).

Peneliti tertarik untuk melakukan penelitian di Pondok Pesantren Disabilitas Achsaniyyah Pedawang Kudus karena selain memberikan pendidikan secara formal juga menyelenggarakan pendidikan vokasi atau keterampilan untuk hidup. Dalam prosesnya, kelas pembelajaran terbagi menjadi beberapa diantaranya kelas one by one, pra-mandiri, dan kelas mandiri. Pondok Pesantren Disabilitas Achsaniyyah Pedawang Kudus juga memberikan terapi pada santri atau siswanya supaya dapat berbaur dengan masyarakat dan tidak merasa terkucilkan. Hal ini dikarenakan para santri atau siswa tersebut sudah memiliki kemandirian sekaligus mampu untuk diajak berkomunikasi dengan lancar.

Paradigma yang beredar di masyarakat terhadap anak disabilitas yaitu sebagai anak yang terabaikan dan tidak bisa untuk disembuhkan. Akan tetapi di Pondok Pesantren ini, guru atau konselor yang juga berperan sebagai ustadz/dzah, pendamping dan juga terapis mampu menghilangkan paradigma tersebut karena 
mampu memberikan nilai lebih bahwasannya anak disabilitas sendiri dapat disembuhkan secara total. Selain alasan tersebut, peneliti juga tertarik pada pembelajarannya yang memberikan sistem 24 jam dengan berlandaskan nilai-nilai keislaman.

Penelitian ini dilakukan untuk menjawab rumusan masalah penelitian, yaitu apakah strategi konselor dalam membantu penyesuaian diri anak berkebutuhan khusus di era milenial. Adapun tujuan penelitian ini adalah untuk mengetahui bagaimana strategi seorang konselor dalam proses bimbingan dan konseling yang sesuai terhadap anak berkebutuhan khusus berkaitan dengan proses penyesuaian diri ABK di era milenial.

Penelitian ini dilaksanakan di Pondok Pesantren Disabilitas Achsaniyyah Pedawang Kudus. Pendekatan dalam kajian ini menggunakan pendekatan deskriptif kualitatif. Pengumpulan data dilakukan dengan teknik wawancara, observasi dan dokumentasi. Adapun yang menjadi subjek penelitian yaitu meliputi guru kelas, dan kepala sekolah atau kepala pondok.

Penelitian kualitatif dipilih karena dalam penelitian ini berusaha mengungkapkan secara menyeluruh tentang manajemen pembelajaran pada anak disabilitas. Dalam penelitian kualitatif, peneliti merupakan instrument utama penelitian, dimana peneliti sebagai perencana yang sekaligus menetapkan fokus, memilih informan, sebagai pelaksana pengumpulan data, menafsirkan data, menarik kesimpulan sementara, dan menganalisis data di lapangan yang alami tanpa dibuat-buat. Sudarwin (dalam Rofiq, 2013) menyatakan bahwa peneliti sebagai instrumen dalam penelitian kualitatif mengandung arti bahwa peneliti melakukan kerja lapangan secara langsung dan bersama beraktifitas dengan orang-orang yang diteliti untuk pengumpulan data. 


\section{B. Pembahasan}

\section{Pondok Pesantren Disabilitas Achsaniyyah Pedawang, Kab. Kudus.}

Berdirinya Pondok ini dilatarbelakangi oleh termotivasinya seorang Faiq Aftoni yang ingin membuat pondok seperti di Gontor (Pondok Modern). Pengasuh pondok (KH. M. Faiq Aftoni, M. Ac., MCH.) tersebut, sadar dan tertarik sekaligus memiliki keprihatinan tersendiri kepada anak-anak penderita disabilitas. Kebanyakan dari mereka terlantar di jalan dan tidak mendapat perhatian dari publik. Begitu juga bagi lembaga-lembaga pendidikan Islam tertentu, keberadaan anak disabilitas masih dipandang sebelah mata. Perhatian lembaga pendidikan Islam terhadap kebutuhan layanan pendidikan bagi penyandang disabilitas menjadi keniscayaan. Hal tersebut memotivasi pengasuh pondok untuk mendirikan pondok pesantren khusus penyandang disabilitas. Seiring perjalanan waktu, maka berdirilah pondok pesantren disabilitas Achsaniyyah yang difokuskan untuk anak-anak disabilitas.

Anak-anak disabilitas harus dipandang seperti orang normal pada umumnya karena mereka juga makhluk Allah yang membutuhkan perhatian yang sama dengan yang lain. Pondok ini berdiri pada tahun 2007. Akan tetapi, aktivitas pendidikan dan layanan pesantren baru aktif dan berjalan normal pada tahun 2010. Awal berdirinya di pedawang Kudus ini karena ada orang yang mewakafkan tanahnya kemudian didirikan ponpes disabilitas Achsaniyyah di lokasi tersebut.

\section{Strategi Konselor di Pondok Pesantren Disabilitas Achsaniyyah Pedawang Kudus.}

Anak autis banyak diantaranya yang disebabkan karena abnormalitas di otak. Karakteristik umum dari gangguan ini ditandai dengan adanya gangguan dalam kognisi sosial, kemampuan sosial, dan interaksi sosial. Anak autis seringkali menunjukkan sifat-sifat kelainan yang bisa diidentifikasi sejak sebelum umur 3 tahun (Semiawan dan Mangunsong, 2010). Menurut Smith (Smith,2006) sifat-sifat tersebut antara lain sebagai berikut: a) Tidak tanggap terhadap orang lain, b) 
Gerakan diulang-ulang seperti bergoyang, berputar, dan memilin tangan. Menghindari kontak mata dengan orang lain, c) Tetap dalam kebiasaan, Ciri-ciri sifat tersebut baru bisa dikatakan sebagai perwujudan autisme apabila terjadi dalam intensitas yang tinggi.

Menurut Sousa (dalam Semiawan dan Mangunsong, 2010), autis dikelompokkan dalam 4 tipe sebagai berikut.

a. Tipe kanner, yaitu tipe klasik atau juga disebut autisme infantil, ditandai oleh ciri-ciri meliputi menghindar kontak mata, lamban berbicara, perilaku mengulang, dan kemungkinan retardasi mental.

b. Sindrom Asperger (SA), yaitu perkembangan perilaku menentang yang spektrum cirinya adalah defisit sosial, namun perkembangan kognisi, dan bahasa relatif normal, serta minal yang mendalam dalam idiosynkretis.

c. Perkembangan perilaku menentang tanpa tanda-tanda lain, kecuali dalam perkembangannya anak ini tidak memenuhi gejala-gejala tersebut sebelum umur 3 tahun. Kadang kala klasifikasi ini digunakan apabila kondisi ini muncul meskipun tidak terlalu berat dan tidak konsisten, sehingga tipe ini kurang kurang diperkirakan sebagai tipe kenner.

d. Tipe regresif/epileptis, tipe ini ditandai dengan ketidakmampuan memahami orang lain, input sensori yang tidak menentu, bacaan EEG yang tidak normal, retardasi mental dan tingkat kecerdasan tinggi.

Dari tipe-tipe autis diatas seorang konselor perlu menyesuaikan diri, khususnya dalam proses konseling ataupun proses pembelajaran anak disabilitas. Menurut M. Sobry Sutikno (2009: 88) metode pembelajaran adalah cara-cara menyajikan materi pelajaran yang dilakukan oleh pendidik agar terjadi proses pembelajaran pada siswa dalam upaya untuk mencapai tujuan.

Berdasarkan hasil wawancara dengan kepala sekolah atau kepala pondok, proses pembelajaran di Ponpes Disabilitas Achsaniyyah Pedawang Kudus memiliki kesamaan dengan pendidikan anak berkebutuhan khusus pada umumnya. Sisi 
lainya yang berbeda dan tidak ditemukan ditempat lain adalah bahwa disana menggunakan sistem penggalian bakat yang dibagi dalam 3 kelas. Kelas one by one, kelas pra-mandiri, dan kelas mandiri. Dengan pembagian kelas ini memungkinkan seorang konselor untuk lebih mudah menangani peserta didik yang tergolong disabilitas.

\section{a. Kelas One by One}

Di kelas one by one ini di peruntukkan santri atau peserta didik yang baru masuk. Kelas tersebut merupakan kelas khusus pada bulan pertama sampai santri atau siswa tersebut dapat terkendalikan kehyperannya. Kelas one by one berupa satu ruang kelas berukuran $250 \mathrm{~cm}$ x $300 \mathrm{~cm}$ yang di isi satu orang guru dan satu orang santri atau siswa tetap per kelasnya. Yang dimaksud adalah berpasangan antara guru dengan siswa atau santri sampai siswa atau santri tersebut mampu mengendalikan kehyperannya tanpa ada campur tangan dari pihak guru.

Tujuan dari kelas tersebut adalah agar siswa atau santri baru mendapatkan perhatian yang lebih dan sangat mendalam terhadap dirinya dan menjadikan guru itu sebagai sosok sahabat yang penuh perhatian di lingkungan barunya. Hal ini dilakukan karena anak disabilitas sangat sulit untuk bersosialisasi langsung dengan lingkungan sekitar tanpa suatu perhatiaan khusus. Dengan memberikan perhatian, motivasi dan juga bimbingan yang besar, maka hal ini dapat membantu anak disabilitas berkembang lebih baik lagi. Akan tetapi, semua itu membutuhkan kesabaran dan ketelatenan ekstra bagi seorang guru supaya bisa memberikan perhatian, motivasi, dan juga bimbingan yang maksimal.

Di kelas One by One, posisi guru bukan hanya sebagai motivator dan melakukan bimbingan yang lebih. Seorang guru dituntut harus bisa melakukan pendekatan emosional. Karena pendekatan emosional juga merupakan salah satu hal penting yang harus ada untuk menghadapi anak disabilitas. Supaya anak dapat percaya dengan kehadiran sosok seorang guru dan mau menjadi dekat dengannya. 


\section{b. Kelas Pra Mandiri}

Setelah dalam beberapa bulan anak yang memiliki kecenderungan hyper aktif dapat terkendalikan, siswa atau santri tersebut dipindahkan ke kelas pra mandiri. Kelas pra mandiri memiliki ruang kelas yang lebih besar dibandingkan kelas One by One. Satu ruang kelas pra mandiri di isi sekitar 10 sampai 15 siswa atau santri. Setiap ruang kelas dibedakan antara laki-laki dan perempuan agar tidak terdapat atau menimbulkan hal-hal yang tidak diinginkan. Dengan guru yang berbeda-beda setiap harinya.

Di kelas pra mandiri, setiap kelas di isi oleh satu orang guru dan ada pula yang satu kelas diisi oleh dua orang guru. Hal ini tergantung pada tingkat kesulitan dalam memberikan pelajaran di kelas tersebut. Ketika satu kelas di isi oleh dua orang guru, satu orang guru memaparkan pelajaran dan satu orang guru lainnya membimbing siswa-siswa atau santri-santri untuk memerhatikan pelajaran.

Kelas pra mandiri bertujuan agar alumni dari kelas One by One tersebut dapat bersosialisasi dengan orang disekitarnya. Tanpa adanya penerimaan dan dukungan dari orang di sekitar, dapat dipastikan anak disabilitas tidak akan mampu mencapai potensinya dengan baik dan optimal. Di kelas ini, peran guru sangat penting dalam tata cara berperilaku anak disabilitas. Kelas ini mengajarkan mengenai bagaimana tata cara bersosialisasi yang baik terhadap orang lain, tata cara bertingkah laku dengan teman sebaya maupun orang yang lebih tua dengannya, sampai tata cara beribadah kepada Allah dengan baik dan benar. Siswa atau santri yang dianggap telah bisa bersosialisasi penuh dengan lingkungan sekitar akan naik tingkat ke kelas mandiri.

\section{c. Kelas Mandiri}

Selanjutnya, setelah siswa siswi atau santri dapat bersosialisasi baik dengan teman maupun dengan guru atau lingkungan disekitarnya, siswa atau santri tersebut dipindahkan ke kelas mandiri. Di kelas ini dapat dikatakan sebagai kelas besar karena berisi sekitar 30 siswa atau santri lebih. Pada kelas ini, proses 
pengembangan dan penggalian bakat dilakukan. Berbeda dengan sekolah-sekolah pada umumnya yang menggunakan kurikulum yang telah ditetapkan oleh pemerintah, Pondok Pesantren ini tidak bisa menerapkan secara penuh atau keseluruhan apa yang ada di dalam kurikulum tersebut. Hal ini dikarenakan percuma bila memberikan banyak materi seperti Matematika, IPA, IPS dan lainnya, namun santri atau siswa tersebut tidak memiliki bakat-bakat dalam hal itu. Pembelajaran seperti matematika, IPA, dan IPS diberikan kepada siswa atau santri dengan maksud supaya siswa atau santri tersebut mengetahuinya tanpa memelajari secara mendalam.

Sebagai gantinya, pondok pesantren memberikan banyak materi lain. Tujuan dari ada banyaknya materi yang diberikan kepada sisiwa siswi atau santri tersebut adalah agar guru bisa menganalisis dimanakah bakat dari mereka masingmasing. Ketika sudah ditemukan bakatnya, maka dilakukan penguatan melalui pembelajaran lebih lanjut sesuai dengan bakat masing-masing. Setelah target dari Pondok Pesantren sudah terpenuhi untuk menjadikan siswa siswi atau santri itu mandiri dan mempunyai keterampilan dalam mengembangkan bakatnya, maka siswa-siswi atau santri bisa untuk pulang kerumah masing-masing.

\section{Hambatan yang sering dihadapi dalam proses pembelajaran.}

Suatu tugas, pekerjaan dan pembelajaran, tidak akan terlaksana apabila ada suatu hambatan yang mengganggu pekerjaan tersebut. Menurut Kamus Besar Bahasa Indonesia (2002: 385) hambatan adalah halangan atau rintangan. Hambatan memiliki arti yang sangat penting dalam setiap melaksanakan suatu tugas atau pekerjaan. Hambatan merupakan keadaan yang dapat menyebabkan pelaksanaan terganggu dan tidak terlaksana dengan baik. Proses belajar mengajar tidak semulus yang dikira. Baik di sekolah formal maupun luar biasa memunyai hambatan dan kendala yang harus dihadapi.

Faktor yang menghambat belajar siswa siswi atau santri di Pondok Pesantren Disabilitas Achsaniyyah secara umum dibedakan menjadi faktor 
internal dan faktor eksternal. Kedua faktor tersebut yang memengaruhi hasil belajar anak.

\section{a. Faktor Internal}

Faktor ini merupakan faktor yang berasal dari dalam individu. Faktor internal meliputi fisiologis dan biologis serta dapat memengaruhi hasil belajar individu. Faktor internal yang sering dihadapi para guru adalah ketika emosi dari siswa siswi atau santri tersebut naik. Seakan-akan siswa siswi atau santri disabilitas tidak punya semangat lagi untuk belajar karena minat dan motivasinya sudah menurun.

\section{b. Faktor Eksternal}

Faktor eksternal adalah faktor dari luar yang dapat memengaruhi hasil belajar siswa siswi atau santri. Faktor ini meliputi faktor lingkungan social, dan non sosial. Yang sering dihadapi oleh para guru yaitu ketika dalam proses pembelajaran, anak tiba-tiba tantrum, atau keadaan dimana anak ini sudah tidak mood. Wujud tidak mood dari anak ini dikarenakan keinginan orang tua dengan lembaga tidak sinkron. Padahal lembaga lebih tahu kemauan, dan hal hal yang dibutuhkan pada anak serta tidak boleh egois terhadapnya. Dalam hal ini, anak berkebutuhan khusus butuh untuk dipahami dan dia punya dunia lain yang tidak diketahui oleh orang yang normal.

Menjadi guru di Sekolah Luar Biasa tidak semudah membalikkan telapak tangan. Salah satu strateginya adalah guru harus memunyai kesabaran yang tinggi dan juga memunyai sifat ikhlas dalam menghadapi anak-anak berkebutuhan khusus. Hal tersebut yang juga dilakukan oleh guru-guru yang ada di Pondok Pesantren Disabilitas Achsaniyyah Pedawang Kudus dalam menghadapi anak-anak tersebut. Menurut hasil wawancara terhadap salah seorang narasumber, tidak jarang siswa siswi suka membanting barang-barang yang ada di sekelilingnya. Ada juga yang pernah terjadi kasus siswa atau santri yang berusaha kabur karena tidak nyaman di lingkungan pondok, dan akhirnya ditemukan kembali oleh keamanan lalu dikembalikan lagi ke pondok. Oleh karena itu, semua pengasuh yang ada di pondok baik security, guru, sampai cleaning servis harus mempunyai kesabaran yang ekstra dalam menangani anak berkebutuhan khusus. 


\section{Bentuk dan metode terapi serta solusi yang dilakukan untuk mengatasi hambatan dalam proses pembelajaran}

Selain menjalankan proses pembelajaran, Pondok Pesantren Disabilitas juga melaksanakan terapi terhadap anak-anak autis. Autis bukanlah sebuah kecacatan fisik, namun sebuah gangguan perkembangan pada anak yang gejalanya sudah timbul sebelum anak itu mencapai usia tiga tahun. Autis dapat disembuhkan lewat terapi untuk merubah sikap hidupnya agar bisa berkomunikasi dengan lancar terhadap orang disekitarnya. Terapi yang dilakukan disini sama seperti sekolah luar biasa pada umumnya dengan memberikan pujian dan kegiatan rutinitas kesenangannya.

Noviza (2005: 9) mengungkapkan bahwa metode terapi merupakan salah satu metode yang dapat digunakan terhadap penderita autism. Menurut Noviza (2005:42) metode terapi tersebut meliputi sebagai berikut:

a. Metode Terapi Applied Behavioral Analysis (ABA): ABA adalah jenis terapi yang telah lama dipakai, telah dilakukan penelitian dan didesain khusus anak-anak penyandang autisme. Metode yang dipakai dalam terapi ini adalah dengan memberi pelatihan khusus pada anak dengan memberikan positive reinforcement (hadiah/pujian).

b. Metode terapi TEACCH: TEACCH adalah Treatment and education of autistic and Related Communication Handicapped Children, yaitu suatu metode yang dilakukan untuk mendidik anak autis dengan menggunakan kekuatan relatifnya pada hal terstruktur dan kesenangannya pada rutinitas dan hal-hal yang dapat diperkirakan dan relatif mampu berhasil pada lingkungan yang visual dibanding yang auditori.

Dengan perbedaan dan keterbatasan kemampuan serta bakat siswa siswi atau santri disabilitas tentu dapat menghambat proses belajar mengajar yang dilakukan. Keterbatasan dan hambatan yang terkait dengan kemampuan intelektual siswa siswi atau santri ini merupakan aspek alami atau natural yang 
tidak dapat dihindari. Meskipun demikian, masalah hambatan ini bukan tidak dapat diatasi. Dalam hal ini, guru harus mampu mengidentifikasi sejauh mana kemampuan dan bakat setiap individu.

Guru secepat mungkin harus mempunyai solusi dalam menghadapi hambatan yang ada. Solusi yang diterapkan di sini biasanya diberikan pada waktu hambatan itu terjadi. Guru dengan cepat mengganti strategi pembelajarannya agar siswa siswi atau santri yang menghadapi hambatan bisa memecahkan permasalahannya dan bisa mengikuti proses pembelajaran kembali. Setiap di akhir tahun diadakan evaluasi pembelajaran untuk mengetahui apakah anak tersebut sudah mencapai yang diharapkan atau belum. Ketika belum mencapai apa yang diharapkan, dicari penyebab lainnya seperti apakah anak membutuhkan perhatian yang ekstra atau cara kita menyampaikan materi metodenya kurang tepat, atau mungkin beda visi dengannya.

Berdasarkan hasil penelitian atau pengamatan di Pondok Pesantren Disabilitas Achsaniyyah Pedawang Kudus, peneliti mengambil sampel 1 anak yaitu bernama Muhammad Rayhan Anugrah. Santri ini berasal dari Makassar, dia adalah salah satu penyandang autis. Anak ini memiliki kelebihan yang berbeda dari teman-temannya. Salah satu kelebihannya adalah bisa mengetahui seri-seri Hp dan Laptop yang hanya dilihat sekilas saja. Selain itu, dia juga pandai mengaji dan memiliki cita-cita belajar agama lebih mendalam. Rayhan juga mempunyai daya ingat yang sangat tinggi dan memiliki ketergantungan pada gadget.

Rayhan lahir di Makassar, 29 juni 2000. Dia masuk ke dalam klasifikasi autis pada masa kanak-kanak. Pada waktu itu, usianya belum sampai 3 tahun dan anak ini sudah kelihatan kehyperannya. Pada akhirnya, orang tuanya memutuskan untuk memasukkan Rayhan ke salah satu tempat rehabilitas yang ada di Bandung. Setelah masuk di tempat ini Rayhan semakin parah, hal ini disebabkan karena salah masuk tempat rehabilitas dan metode yang digunakan kurang tepat. Tempat rehabilitas yang ada di Bandung ini merupakan tempat rehabilitas bagi orang- 
orang pecandu narkoba, sedangkan Rayhan sendiri ini adalah anak penyandang autis. Karena lingkungan yang berbeda, Rayhan semakin hari semakin memberontak.

Rayhan awal masuk Pondok Pesantren Achsaniyyah pada tanggal 24 September 2017. Langkah awal yang dilakukan terhadap anak-anak baru yaitu mengobservasi dan masuk ke dunia mereka untuk mengetahui sifat dan kemauan mereka. Rayhan sendiri butuh waktu tiga bulan untuk menyetabilkan kehyperan dan kebiasaan-kebiasaan buruknya. Kebiasaan buruk Rayhan diantaranya adalah suka merusak barang-barang, suka mukul-mukul temannya, dan lain sebagainya. Rayhan awal masuk di ponpes Achsaniyyah juga sempat ingin kabur, tapi alhamdulillah bisa teratasi. Seiring berjalannya waktu, orang tua Rayhan senang dengan kemajuan anaknya yang berubah menjadi pribadi yang santun dan bisa diinstruksi hanya dalam waktu satu tahun. Setelah ada kemajuan yang cukup signifikan, Rayhan ditarik ke kelas mandiri. Di kelas mandiri ini proses belajarnya beda sedikit dengan di kelas pra mandiri, di kelas mandiri ini lebih memfokuskan kepada praktik dan diajari ekstrakulikuler yang ada.

Proses pembelajaran disana sebenarnya sama seperti di sekolah-sekolah formal pada umumnya, meliputi pelajaran Bahasa Indonesia, Matematika, dan lain sebagainya. Meskipun demikian, dalam hal pembelajaran mata pelajaran tersebut, guru harus pandai-pandai menyederhanakan cara dan bahasa agar mudah dipahami oleh anak-anak. Untuk kelas pra mandiri satu kelas berisi sekitar 10 orang dengan satu orang guru. Anak pra mandiri ini diajari satu per satu. Waktu pembelajaran satu harinya hanya satu mata pelajaran, dari mulai pukul 08.0012.00. pada pukul 09.00 adalah waktu istirahat, di waktu istirahat ini adalah waktu anak-anak makan dimana guru kelas menyuapi satu per satu anak didiknya. Setelah itu, biasanya diisi dengan permainan-permainan. Evaluasi pembelajaran dilaksanakan pada akhir tahun, adapun hal yang di evaluasi adalah berhasil tidaknya strategi proses pembelajaran yang diterapkan. 


\section{Strategi Konselor Terhadap Anak Disabilitas}

Bimbingan dan konseling merupakan salah satu unsur dalam progam pendidikan di sekolah. Dalam sistem pendidikan, terdapat 3 (tiga) aspek kerangka pendidikan seperti administrasi dan supervise, pengajaran kulikuler, dan bimbingan dan konseling. Dari tiga aspek tersebut jika dapat terlaksana dengan baik, maka akan menghasilkan tujuan pendidikan yang optimal bagi individu (Luki Umami, 2018: 459).

Pemberian bantuan tidak hanya diberikan pada anak normal saja, tetapi anak autis dan disabilitas juga perlu mendapatkan bantuan. Berdasarkan perkembangan pandangan masyarakat terhadap anak tersebut, masih banyak anak berkebutuhan khusus yang terabaikan sampai saat ini. Sebagian besar masyarakat masih ada yang menganggap kecacatan atau kelainan yang disandang oleh anak berkebutuhan khusus sebagai kutukan, penyakit menular, gila, dan lain-lain. Akibatnya, anak-anak tersebut dan keluarga ada yang dikucilkan oleh masyarakat. Ada diantara mereka yang menarik diri dan tidak mau berbaur dengan masyarakat karena merasa cemas dan terancam.

Di era globalisasi dimana teknologi digital dapat diakses oleh hampir semua kalangan, informasi berkembang dengan pesat dan penyebarannya semakin cepat. Di era digital sekarang ini, media konvensional masih tetap eksis, namun telah ditinggalkan oleh generasi yang lahir di era digital, yaitu generasi Millennial. Bagi generasi millennial untuk melindungi diri dari informasi yang tidak akurat, bersifat provokasi, pola perilaku penggunaan media harus dievaluasi dan diperbaiki supaya tidak jatuh pada informasi hoax yang bersumber dari opini satu orang ataupun berita viral yang tidak diketahui dari mana berita bersumber (Ratih, 2017).

Dalam era milenial dan perkembangan zaman ini, maka proses konseling lebih menekankan pada pengembangan potensi dari didalam dirinya. Yang termasuk dalam potensi tersebut adalah aspek intelektual, sosial, emosional, dan 
religius, sehingga individu akan berkembang dengan nuansa yang lebih bermakna, harmonis sosial dan bermanfaat. Konseling bagi anak berkebutuhan khusus merupakan upaya bantuan yang diberikan oleh konselor kepada konseli (ABK) tersebut agar dapat menyelesaikan masalah yang sedang dihadapinya dan mampu menyesuaikan diri dengan lingkungan yang berbeda dengan dirinya. Serta mampu untuk mengembangkan potensi yang dimiliki sesuai dengan kemampuan dan bisa dikembangkan menjadi bakat yang berguna untuk kariernya.

Tujuan diadakannya bimbingan konseling terhadap anak berkebutuhan khusus ini, Thompson dkk (2004) dalam bukunya Counseling Children: sixth ed. menuliskan garis besarnya sebagai berikut: a) Anak harus mengenal dirinya sendiri, b) Menemukan kebutuhan ABK yang spesifik sesuai dengan kelainannya. Kebutuhan ini muncul menyertai kelainannya, c) Menemukan konsep diri, d) Memfasilitasi penyesuaian terhadap kelainan/kecacatannya, d) Berkoordinasi dengan ahli lain, e) Melakukan konseling terhadap keluarga ABK, e) Membantu perkembangan ABK agar berkembang efektif dan memiliki keterampilan hidup mandiri, f) Membuka peluang kegiatan rekreasi dan mengembangkan hobi, g) Mengembangkan keterampilan personal dan sosial.

Tujuan tersebut diharapkan dapat terpenuhi melalui berbagai layanan bimbingan dan konseling yang dilakukan oleh konselor. Layanan bimbingan dan konseling tersebut disesuaikan dengan kebutuhan dan kemampuan dari anak berkebutuhan khusus. Dalam pemberian layanan, konselor umumnya didampingi oleh satu orang guru lain yang membantu pembelajaran siswa berkebutuhan khusus. Layanan bimbingan dan konseling terutama diarahkan pada membantu siswa agar dapat menyesuaikan diri baik dengan dirinya sendiri maupun lingkungan di sekitarnya. Layanan bimbingan dan konseling yang diberikan seperti pemberian layanan orientasi, informasi, dan lain sebagainya. 


\section{Simpulan}

Semua tempat pembelajaran dituntut harus mampu dan dapat memberikan pendidikan sesuai dengan perkembangan zaman pada saat ini. Begitu juga dengan sekolah untuk Anak Berkebutuhan Khusus. Sekolah harus mampu menerapkan berbagai macam strategi agar dapat mewujudkan siswa siswi generasi milenial yang tahu dan dapat mengaplikasikan teknologi. Pelaksanaan pendidikan terhadap Anak Berkebutuhan Khusus tidak semudah membalikkan telapak tangan. Banyak hal yang harus dipersiapkan secara matang dalam melaksanakan pendidikan tersebut. Pemberian pelayanan dan pendekatan secara khusus dari guru untuk memberikan support dan penggalian bakat setiap individu harus dapat diterapkan agar dapat mencapai tujuan pendidikan secara maksimal. Guru harus mampu mendidik siswa siswi ABK supaya dapat hidup mandiri, bisa menyelesaikan permasalahan setiap individu, dan mampu bersosialisasi pada masyarakat umumnya.

Dalam hal ini strategi yang digunakan oleh Pondok Pesantren Disabilitas Achsaniyah Pedawang membagi kelas menjadi 3, yaitu : a) Kelas One by One, kelas ini diperuntukkan bagi santri atau peserta didik yang baru masuk. Kelas tersebut merupakan kelas khusus pada bulan pertama sampai santri atau siswa tersebut dapat terkendalikan kehyperannya, b) Kelas Pra Mandiri, kelas ini bertujuan agar alumni dari kelas One by One dapat bersosialisasi dengan orang disekitarnya, c) Kelas Mandiri, kelas di mana siswa siswi atau santri telah dapat bersosialisasi secara baik dengan teman maupun dengan guru atau lingkungan disekitarnya. Di kelas ini, siswa dikembangkan potensinya sesuai dengan bakat yang dimiliki oleh siswa tersebut. Sementara itu, strategi seorang konselor dalam membantu anak berkebutuhan khusus tercermin dalam pemberian berbagai layanan bimbingan dan konseling yang disesuaikan dengan kebutuhan dan kemampuan anak. 


\section{Daftar Pustaka}

Anonim. 2006. UUD 1945 \& Konstitusi Indonesia. Jakarta: Indonesia Legal Center Pulishing.

Chamidah. 2010. Mengenal Anak Berkebutuhan Khusus. Yogyakarta: UNY.

Departemen Pendidikan Nasional. 2002. Kamus Besar Bahasa Indonesia. Jakarta: Balai Pustaka.

Kamaluddin. 2011. Bimbingan dan Konseling Sekolah. Jurnal Pendidikan dan Kebudayaan, Vol. 17, Nomor 4, Juli 2011.

Kamus Besar Bahasa Indonesia. 2002. Edisi Ketiga Bahasa Depdiknas. Jakarta: Balai Pustaka.

Luki, Umami. 2018. Bimbingan Dan Konseling Dengan Teknik Multikultural Terhadap Anak Berkebutuhan Khusus Di Sekolah Inklusi. JMP Online Vol. 2 No. 5 Mei (2018) 456-468

Noviza, Neni. 2005. Progam Penata Laksanaan Perilaku Hiperaktif pada Anak Autisti. Tesis. Bandung: UPI.

Rahman, Muzdalifah M. Pendidikan Keluarga Berwawasan Gender pada Anak Berkebutuhan Khusus di Kudus. Jurnal Palastren, Vol. 9, No. 1, Juni 2016.

Ratih, Ellysabeth. 2017. Literasi Media Generasi Millenial di Era Media Sosial. Feature: Millennials Mind.

Permendiknas. 2009. Permendiknas No 70 Tahun 2009 Tentang INKLUSI. Peduli inklusi.

Rofiq, Aunu. 2013. Teknik Pengumpulan Data Dalam Penelitian Kualitatif. Majalah Ilmiah Pawiyatan. Jilid 20/16 Maret 2013.

Roihah. 2015. Bab II Kajian Teori Anak Berkebutuhan Khusus. Skripsi. UINMALANG.

Semiawan, C. R., \& Mangunsong, F. 2010. Keluarbiasaan Ganda (Twice Exceptionality): Mengeksplorasi, Mengenal, Mengidentifikasi, dan Menanganinya. Jakarta: Kencana Perdana Media Group.

Smith, D. J. 2006. Inklusi, Sekolah Ramah untuk Semua. Bandung: Nuansa.

Suffa. 2014. Penerapan Bimbingan Dan Konseling Bagi Anak Berkebutuhan Khusus Di Smalb Negeri Ungaran. Skripsi. IAIN Walisongo.

Sutikno, M. Sobry. 2009. Belajar dan Pembelajaran. Bandung: Prospect.

Thompson, Charles. L., Rudolph, Linda B., \& Henderson, Donna A. 2004. Counseling Children: Sixth Edition. USA: Brooks/Cole Company. 